\title{
Who is Theophilus? Discovering the original reader of Luke-Acts
}

\author{
Authors: \\ Jennifer M. Creamer ${ }^{1}$ \\ Aida B. Spencer ${ }^{1}$ \\ Francois P. Vijoen ${ }^{1}$ \\ Affiliations: \\ ${ }^{1}$ Faculty of Theology, \\ North-West University, \\ Potchefstroom Campus, \\ South Africa \\ Correspondence to: \\ Francois Vijoen \\ Email: \\ viljoen.francois@nwu.ac.za \\ Postal address: \\ Private Bag X6001 \\ Potchefstroom 2520, \\ South Africa \\ Dates: \\ Received: 30 July 2013 \\ Accepted: 10 Dec. 2013 \\ Published: 19 June 2014 \\ How to cite this article: \\ Creamer, J.M., Spencer, A.B. \\ \& Vijoen, F.P., 2014, 'Who \\ is Theophilus? Discovering \\ the original reader of Luke- \\ Acts', In die Skriflig 48(1), \\ Art. \#1701, 7 pages. http:// \\ dx.doi.org/10.4102/ids. \\ v48i1.1701

\section{Copyright:} \\ (C) 2014. The Authors. \\ Licensee: AOSIS \\ OpenJournals. This work \\ is licensed under the \\ Creative Commons \\ Attribution License.
}

Read online:
The aim of this article is to investigate the nature of Theophilus as the original reader of LukeActs. A lexical and grammatical analysis of Luke 1:1-4 and of the broader literary context of the Luke-Acts narrative provided the basis for discovering the identity of Theophilus. This article proposes that Theophilus was a man of prominent position: a Gentile who had received some introductory teachings about Christ and who needed factual verification of the events surrounding the emergence of Christianity.

Wie is Teofilus? 'n Ondersoek na die oorspronklike leser van Lukas-Handelinge. Die doel van hierdie artikel is om Theophilus, as die oorspronklike leser van Lukas-Handelinge, se identiteit te ondersoek. 'n Leksikale en grammatikale ontleding van Lukas 1:1-4, asook 'n ontleding van die breër literêre konteks van die Lukas-Handelinge-narratief, bied die basis vir die ontdekking van Theophilus se identiteit. Hierdie artikel stel Theophilus voor as 'n man met 'n prominente posisie: ' $n$ nie-Jood wat basiese Christusonderrig ontvang het en wat die bevestiging van die gebeure rondom die opkoms van die Christendom voorop gestel het.

\section{Introduction}

The Luke-Acts narrative comprises nearly $26 \%$ of the New Testament. Considering the extensive research involved, it is likely that Luke spent several years producing the two-part document that was dedicated, at least initially, to an audience of one: Theophilus. In his monograph, The significance of Theophilus as Luke's reader, Roman Garrison (2004) notes that the original reader of the Luke-Acts narrative has been overlooked by scholars:

Many scholars have disregarded the significance of Theophilus as the intended reader of those books (treating him as irrelevant) and instead have given attention to a generalized Gentile audience that came to read Luke-Acts. (p. 22)

Garrison orients his thesis around the significance of Theophilus in relation to the inevitable choices that Luke would have had to make regarding what material to include or not to include in his writings, rather than on the identity of Theophilus. This article seeks to present primary source material that will help us to answer the foundational question: 'Who is Theophilus?'

Is Theophilus a real person? Johnson (1991:28) allows for the possibility that Theophilus may be a symbolic reference to any reader, since the name means 'lover of God'. Many scholars including Bruce (1990:98); Bock (1994:15, 65); Green (1997:xxxix); Garrison (2004:97); Garland (2011:55-56) and Thompson (2011:428) maintain that Theophilus is indeed a real person. Loveday Alexander (1993:188) notes that the existence of fictional prefaces in some works of Hellenistic literature does not prove that Luke 1:1-4 is also a fictional preface. An examination of lexical and grammatical evidence from the preface will show that Luke intends to present a carefully researched historical document. To understand Theophilus as a general reference to any reader is to ignore the description of a specific person in a specific context (Garrison 2004:26). For the purposes of this article, 'original reader' should be understood as the man, Theophilus, who was the personal recipient of the dedication in the prologue to Luke (Hengel 2012:536). In the pages that follow, lexical, grammatical and literary contexts from the prologue of Luke will be examined as well as contexts from the broader themes of Acts that point to the existence of Theophilus as a real person. We will conclude that Theophilus is a man of position, that he had previously received some introductory teaching about Jesus, and that he needed factual verification of matters pertaining to Jesus and the rise of Christianity.

\section{Most excellent Theophilus}

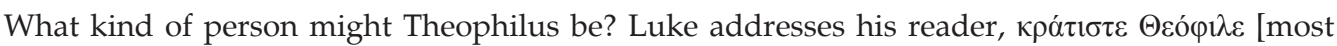

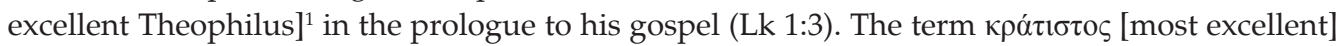

1.Unless otherwise indicated, translations from the New Testament and Septuagint are the author's. 
appears in three other places in the New Testament, solely in writings by Luke. In Acts 23:26, Claudius Lysias begins his letter of appeal on Paul's behalf with 'to the most excellent ( $\tau \tilde{\omega} \kappa \rho \alpha \tau i ́ \sigma \tau \omega)$ governor Felix, greetings'. In Acts 24:3 Tertullus addresses Felix in a court setting with the honorific title 'most

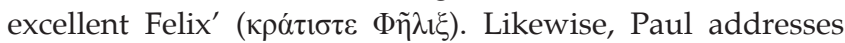

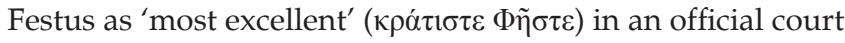
setting (Ac 26:25). These texts show that the honorific title most excellent may be used both in and out of court settings. In every instance in Acts, the term is used in connection with an explicit identification of the person's official status as a Roman governor (also Bock 1994:63).

As we broaden our reading to occurrences outside the New Testament, we find two primary categories of meaning of

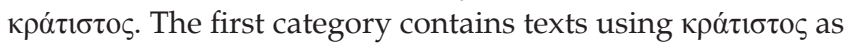
a superlative adjective from $\kappa \rho \alpha \tau$ c $\varsigma$ that may be translated as 'best' (Liddell \& Scott 1996:991). The adjective may identify the elite part from within a larger group. Examples include 'the best of the sheep and of the cattle' (1 Sm 15:15, LXX) and 'forty of the best of his foot soldiers' (Ant. 17.282). ${ }^{2}$ The

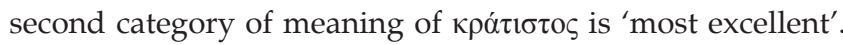
In this domain, it is a superlative adjective, probably from

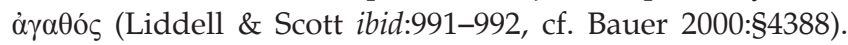
This superlative adjective frequently sits in close proximity to a proper name. This domain is in accord with the contexts

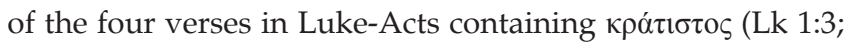

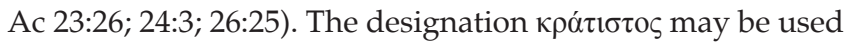
as part of an honorary address to a person of high political standing (Moulton \& Milligan 1930:\$2405; Louw \& Nida 1989:\$3837; Liddell \& Scott ibid:991-992, Thayer 1997:\$3075; Friberg, Friberg \& Miller 2000:\$16573). This is the case with

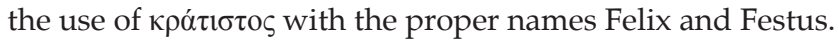

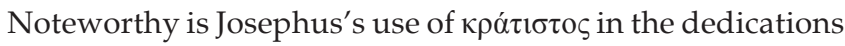
of two of his books Antiquities and Against Apion. He dedicates Antiquities to Epaphroditus (Life 1.430): 'But to you, O Epaphroditus, you most excellent of men! do I dedicate all this treatise of our Antiquities.' Josephus addresses Epaphroditus again in the prologue of Against Apion (Ag. Ap. 1.1): 'I suppose, that by my books of the "Antiquity of the Jews", most excellent Epaphroditus.' Epaphroditus may have been a procurator of Trajan (Josephus 1978:773). Scholars have also suggested that although it is not possible to identify Epaphroditus with certainty, he may have been a former instructor for the son of Marcus Mettius Modestus, an Egyptian prefect or a former secretary to the emperor Nero - with Steve Mason and John Barclay both preferring the latter option (Mason 2001:173; Barclay 2007:3-4). In a fashion similar to his dedications to Epaphroditus, Josephus refers to Vitellius as 'most excellent' in Antiquities 20.12. Earlier in his Antiquities, Josephus refers to Vitellius as 'governor of Syria' (Ant. 15.405). These passages establish that $\kappa \rho \alpha ́ \tau 1 \sigma \tau o \varsigma$ may be used in a formal address to a person of political position or to a person closely associated with the government.
Josephus (Ant. 18.273; 20.13) also refers to members of King

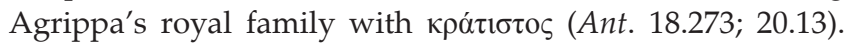
The high position of John Hyrcanus is described in Jewish

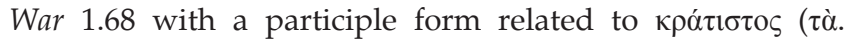
$\kappa \rho \alpha \tau \imath \sigma \tau \varepsilon v ́ o v \tau \alpha)$. These 1st century examples provide evidence

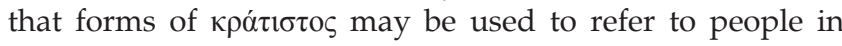
political leadership.

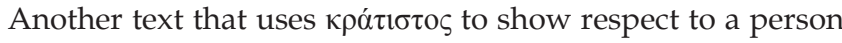
of prominence is found in the Apostolic Fathers. The Epistle to Diognetus uses the vocative form in its dedication to

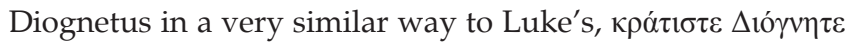
(Ep. Diog. 1.1). Diognetus may have been associated with the royal courts of Hadrian or Marcus Aurelius. The evidence, however, is inconclusive (Holmes 1989:293).

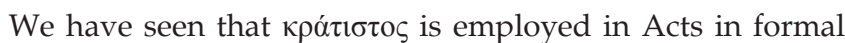

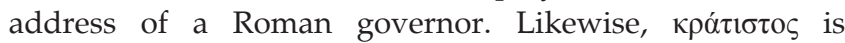
employed in Josephus's writings to address people of position in the Roman government. In our example from the dedication of The Epistle to Diognetus, it is possible that the term is employed to address a person associated with the Roman government. Is Theophilus also a Roman official then? This is a possible scenario. Semantic evidence shows

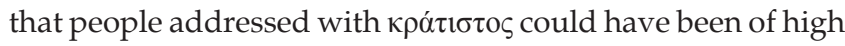
government rank. This lexical study leads us to postulate that Theophilus may have been a man of social standing: he may have been a government official with some measure of authority.

Thus far it has been determined through lexical analysis that Theophilus may have been a person of social and political standing in the Roman government (also Cadbury 1922:505506; Bruce 1990:98; Peterson 2009:102). Loveday Alexander (1993:188) disagrees. In her research she compares the prologue of Luke with prologues from scientific manuals in which the person receiving the dedication is not necessarily of superior rank. Luke-Acts, though, is not a scientific manual (Bock 2007:52). John Moles also disagreeing with Alexander, maintains that Luke follows the tradition of classical historians such as Thucydides and Herodotus (Moles 2011:463).

The context of Acts should be weighed carefully. A look at the broader context of Acts may add further support to the possibility of Theophilus as a person of prominence. We may consider the challenge a historian is faced when choosing which material to include. The historian must be selective with the material in accordance with space limitations and purpose of writing (Schnabel 2012:29). Let us also consider how Luke frequently includes information about various leaders throughout his narrative of the expanding church in Acts. The following are a few examples: Sergius Paulus, the proconsul in Paphos, 'an intelligent man, who summoned Barnabas and Saul and wanted to hear the word of God' (Ac 13:7, NRSV), Lydia, a businesswoman in Philippi (Ac 16:14-15), Greeks with high standing in Beroea (Ac 17:12), and Dionysius the Areopagite (Ac 17:34). ${ }^{3}$ Sergius Paulus,

3.Of further note, Dionysius the Areopagite became the first bishop of Athens according to Eusebius (2007 [Hist. eccl. 3.4]). 
Lydia, the high standing Greeks in Beroea and Dionysius the Areopagite all are said to believe the gospel. Other leaders in Acts are shown to uphold the Pax Romana or to protect unjustly accused Christians from harm: the town clerk in Ephesus ends a riot (Ac 19:35-41), a tribune saves Paul's life (Ac 21:31-32), a centurion stops the illegal flogging of Paul (Ac 22:25-29), Festus proves reasonable in his assessment of Paul's case (Ac 25:25-27), Agrippa affirms Paul's innocence (Ac 26:31-32) and a centurion saves Paul's life (Ac 27:42-43). Why such an emphasis on people of influence in the early days of the church? Why such an emphasis on leaders who do the right thing? Could it be that Luke holds up these leaders as examples and as a point of identification for Theophilus as the reader?

If Theophilus was a person of social standing, it is likely that he also would have been a person of financial means. It could have been possible for him to fund Luke's research (Polhill 1992:79; DeSilva 2000:126; Peterson 2009:102; Garland 2011:56). In an age of patron-client relationships, this may have been a likely scenario (Alexander 1993:190-191). It may be that Theophilus had asked Luke for verification of the events of Jesus' life and teachings. Luke may have written the narrative with the understanding that Theophilus might help fund the dissemination of his work, thereby reaching a broad audience (Peterson ibid:102). This, however, cannot be determined with certainty. Alexander suggests that it is more likely that Theophilus acted as a patron in terms of support for Luke's research than funding the dissemination of that research (Alexander ibid:190-200).

David Garland (2011:56) suggests that the name Theophilus, may have been 'an alias for prominent Roman who needed to remain incognito'. If he was a prominent government official, Theophilus may have desired to keep his true identity concealed for political or safety reasons.

\section{Theophilus and the theme of Gentile inclusion in Acts}

Theophilus would have been, by every indication, a Gentile rather than a Jew. It would have been unlikely for a Jew to hold political office (see also Bock 2007:52). Luke's emphasis on the inclusive nature of the kingdom of God in his gospel as well as the major theme of the breaking in of the Gentiles in Acts, could further support the likelihood that Theophilus was a Gentile.

Bock (1994) suggests that Theophilus may have been a Godfearer before coming to faith in Christ. He lists passages from Acts that refer to Godfearers (including Ac 10:2, 22, $35 ; 13: 16,26,43,50 ; 17: 4,17 ; 18: 7)$ as a possible explanation for their inclusion in the narrative. Bock (ibid:15) notes 'the extensive use of the OT in the two volumes' as further evidence of this possibility. Although the very presence of Old Testament passages and references to Godfearers in the Luke-Acts narrative do not furnish proof that Theophilus was also a Godfearer, their very inclusion seem to imply that Theophilus had at least some knowledge of the Jewish Scriptures - and hence, of the Jewish community.
Whether or not a Godfearer, Theophilus may have had questions regarding the relationship between Jews and Gentiles in the context of Christianity. The narrative of Acts illustrates repeatedly that Christianity is for Greeks and for Jews. Theophilus would have been familiar with the exclusive nature of Judaism. Whether a Godfearer or not, Theophilus never would have been permitted beyond the court of the Gentiles. In contrast, a reading of Luke-Acts highlights the inclusive nature of the kingdom of God under the reign of Christ. Acts, in particular, focuses on Gentile inclusion.

The narration of the irrepressible expansion of the early church in Acts propels the reader into the forward movement of the Gentile mission (Larkin 1995:30-33; Rosner 1998:215-233; Blomberg 2006:17-18; Bovon 2006:348; Bock 2007:6-8). From the ascension of Christ in chapter 1 to the narrative of Paul's house arrest in Rome nearly 30 years later in chapter 28, Luke chronicles the growth of Christianity as it begins with Jews in Jerusalem and continues with the mission to Gentiles throughout the empire.

How might Theophilus as a Gentile have understood this overarching theme of Gentile inclusion? The Holy Spirit has done a new thing in bringing both Jews and Gentiles together in Christ. Gentiles are no longer outsiders - the door of faith has swung wide open. The message of Gentile inclusion is an invitation for those who were previously outside to come in - under the new covenant. There is place for Theophilus in the kingdom of God.

\section{What did Theophilus know about Christianity prior to Luke-Acts?}

Luke indicates that Theophilus had already received some teaching about Christianity when he states that his purpose for writing his gospel in Luke 1:4 is 'that you may know the

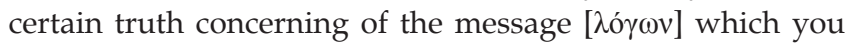
were taught $\left[\kappa \alpha \tau \eta \chi \eta^{\prime} \theta \eta \varsigma\right]^{\prime}$.

What might have been the nature of the message that

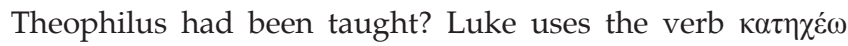
in three additional places: Acts 18:25; $21: 21$ and 21:24. The meaning of $\kappa \alpha \tau \eta \chi \dot{\varepsilon} \omega$ is 'to teach or instruct' in the narrative about Apollos in Acts 18:25 (Bauer 2000:\$4541). Apollos had received some general information about Jesus (Ac 18:25,

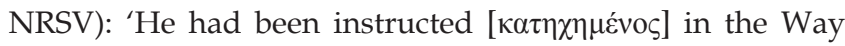
of the Lord [...] and taught accurately the things concerning Jesus', but he only knew of the baptism of John. So, 'when Priscilla and Aquilla heard him, they took him aside and explained the Way of God to him more accurately' (Ac 18:26, NRSV). It seems likely that the teaching Apollos received about Jesus was introductory in nature. In Acts 21:21-24, Luke uses $\kappa \alpha \tau \eta \chi \varepsilon \dot{\varepsilon} \omega$ with a meaning of 'to inform by word of mouth' (Thayer 1997:\$2881). In this particular instance, $\kappa \alpha \tau \eta \chi \dot{\varepsilon} \omega$ refers to an informal oral report that communicated incomplete and inaccurate information. Alexander (1993:139) argues that, in this case, the circumstance of inaccurate information belongs 'to the context, not to the word itself'. 
Alexander also explains that $\kappa \alpha \tau\rceil \chi \dot{\varepsilon} \omega$ usually refers to instruction given in an educational setting and may involve any of a number of academic disciplines. These may include rhetoric, philosophy or the medical arts (Alexander 1993:139). Louw and Nida (1989:\$3627) define $\kappa \alpha \tau \chi \chi \dot{\varepsilon} \omega$ as 'to teach in a systematic or detailed manner'.

Christian writings outside Luke $\kappa \alpha \tau \chi \varepsilon \dot{\varepsilon} \omega$ refer to teaching regarding the faith. It may refer to oral teaching given in a church setting (1 Cor 14:19; Gl 6:6) or instruction from the Scriptures ( $\mathrm{Rm}$ 2:18). Written between the late 1st century AD and the mid-second century AD (Jefford 2012:123), the author of 2 Clement uses $\kappa \alpha \tau \eta \chi \dot{\varepsilon} \omega$ to describe introductory Christian teachings:

For if we have orders that we should make it our business to tear men away from idols and to instruct them, how much more wrong is it that a soul which already knows God should perish? (2 Clem. 17.1)

These contexts fit within the framework offered by Alexander as well as Louw and Nida. Paul's writings and 2 Clement, $\kappa \alpha \tau \eta \chi \varepsilon \dot{\varepsilon} \omega$ refers to religious teachings given in an evangelistic or church setting.

Evidence points to the likelihood that Theophilus had received some kind of instruction about Jesus. That instruction was likely introductory. Could it be that Theophilus himself requested validation from Luke for the teaching he had received? Theophilus' situation may be compared to that of Apollos in Acts 18:24-28. As Priscilla and Aquila took Apollos aside and 'explained the Way of God to him more accurately' (Ac 18:26, NRSV), so Luke writes his first book for Theophilus so that he might know the certain truth regarding Jesus and his teachings. This purpose may extend to the second book too: that Theophilus might know the truth concerning the spread of Christianity.

\section{Theophilus and the verification of the facts: The reliability of Luke-Acts}

What might Theophilus have been hoping to gain through Luke's research? How might Theophilus have known what he was about to read is reliable?

The topic of the accuracy of Luke as a historian has received no shortage of scholarly prose for more than 100 years. Indeed, Bauman and Klauber (1995:41) trace the discussion of the historical reliability of Luke-Acts back to W.M.L. de Wette, a 19th century scholar. Scholarship remains divided on the topic of the historical reliability of Luke-Acts. Notable scholars who question the accuracy of Luke's writings include Dibelius (1956), Haenchen (1971) and Conzelmann (1987). Amongst those who argue in favour of reliability are F.F. Bruce (1976; 1990), Colin Hemer (1977; 1989a; 1989b), I.H. Marshall (1980; 1988) and Darrell Bock (2007).

Gempf (1993) compares the historiography of Acts to the statements of other Greek historians about the nature of their respective works, but does not include a discussion of
Luke's own statement in Luke 1:1-4. This article argues that Luke's work merits a reading in light of the matrix he himself presents in the prologue to his gospel. For this reason, the prologue will be studied in this section with a careful analysis of grammar and style. The aim is to discover Luke's method and motivation by elucidating his own statement of intent in Luke 1:1-4. We will see that Luke intended to furnish Theophilus with a well-researched document based on verifiable evidence. Luke, as the author, would have been writing with Theophilus' needs in mind.

\section{Luke's prologue}

An analysis of the grammar and style of the prologue with particular focus on the last two clauses (vv. 1:3b-4), illuminates Luke's method and intent in writing for Theophilus. The prologue establishes Luke's rationale and purpose for writing, and prepares the reader for the rest of the book (Green 1997:33-36; Stein 1992:66-68). The prologue found in Luke 1:1-4 comprises of one lengthy sentence in Greek. This intricate sentence has one main clause (v. 3). Two subordinate adverbial clauses precede this clause (vv. 1-2) and one subordinate adverbial clause follows (v. 4).

What is Luke's rationale? The opening adverbial clause shows cause by giving grounds for him to write an account. He is not the first to do so (Lk 1:1): 'Since many have set their hand to arrange in proper order an account concerning the events which have been fulfilled among us.' The second subordinate clause flows from the first by means of comparison. This further clarifies the nature of the accounts that have been written, 'just as those who from the beginning, having

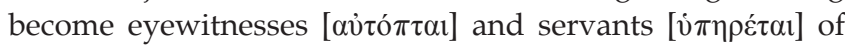
the word, handed down to us' (v. 2). The two nouns $\alpha v ่ \tau o ́ \pi \tau \alpha$. and $\dot{i} \eta \rho \varepsilon \varepsilon^{\prime} \alpha \iota$ have similar cadence and are amongst a rather small number of masculine nouns that take first declension endings. Thus, aspects of repetition in this phrase are carried out in two dimensions, namely sound and visual form. This emphasis serves to draw Theophilus' attention to the author's central point: the content of the narrative finds its roots amongst eyewitnesses. Eyewitnesses provide important evidence in cases requiring a verdict. Given his background as part of the Roman bureaucracy, Theophilus may have appreciated (or even requested) validation of sources.

Since Luke himself was not an eyewitness of the events narrated in his gospel, how may Theophilus be assured of the reliability of his account? Luke conducted careful investigations amongst eyewitnesses in order to produce his gospel. The main clause follows in verse 3: '[I]t seemed

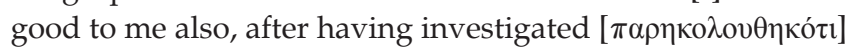
from the beginning everything carefully, in order, to write to you, Most Excellent Theophilus.' The dative participle

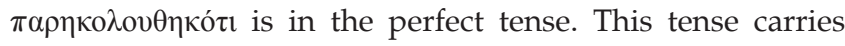
with it a sense of past time with results extending into the present (Wallace 2000:246-247). The research of the past influences the writing of the present. Stanley Porter proposes in his explanation of verbal aspect that the perfect tense may also convey a 'frontground' meaning by bringing emphasis 
right before the reader (Porter 1999:23-24). If this is the case, Luke may have been highlighted the investigative process that preceded his writing in order to capture the attention of his reader. Luke states that he bases his account on verified historical facts. He makes this statement in such a way as to honour Theophilus. Luke is not handing Theophilus work of shoddy scholarship, but a reliable document based on eyewitness evidence.

\section{What is there to gain?}

What does Theophilus have to gain by a reading of Luke's gospel? Another subordinate adverbial clause follows the main clause. This final clause in verse 4 shows Luke's

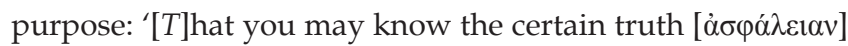
concerning the message which you were taught.' The direct object, $\dot{\alpha} \sigma \varphi \alpha \dot{\lambda} \varepsilon i \alpha v$, has to do with assurance and certainty. This word is frequently employed to indicate security as in with a locked or guarded door (Louw \& Nida 1989:\$994). More specifically, in Luke 1:4 $\dot{\alpha} \sigma \varphi \alpha \dot{\lambda} \varepsilon \varepsilon \alpha$ it has to do with the 'stability of an idea or statement' in the sense of certainty and truth, and 'to be clear about the accounts'. It can also be used as a 'legal term for a written guarantee' (Bauer 2000:\$1229). In his article, Rick Strelan (2007:163) proposes that $\alpha \sigma \varphi \alpha ́ \lambda \varepsilon 1 \alpha$ denotes the sureness of the words and the soundness of their argument' in Luke 1:4. The related adjective $\dot{\alpha} \sigma \varphi \alpha \lambda \eta \varsigma^{\prime}$, surfaces in three particular passages in Acts with the context of the validation (or lack of validation) of the facts pertaining to events that took place. Consider the following:

Some in the crowd shouted one thing, some another; and as he could not learn the facts [ $\alpha \sigma \varphi \alpha \lambda \dot{\varepsilon} \zeta]$ because of the uproar, he ordered him to be brought into the barracks. (Ac 21:34, NRSV)

But on the next day, desiring to know the real reason [ $\left.\alpha \sigma \varphi \alpha \lambda \varepsilon^{\prime} \zeta\right]$ why he was being accused by the Jews, he unbound him and commanded the chief priests and all the council to meet, and he brought Paul down and set him before them. (Ac 22:30, ESV)

But I have nothing definite [ $\dot{\alpha} \sigma \varphi \alpha \lambda \dot{\varepsilon} \varsigma]$ to write to our sovereign about him. Therefore I have brought him before all of you, and especially before you, King Agrippa, so that, after we have examined him, I may have something to write. (Ac 25:26, NRSV)

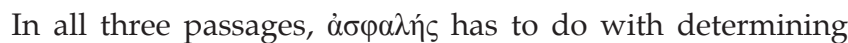
the real facts or the real story pertaining to Paul's charge and arrest. The context is one of needing to find out what really happened in the midst of unclear or uncertain accounts. In Acts 25:26 Festus declares that a judicial examination is necessary before having something definite ( $\dot{\alpha} \sigma \varphi \alpha \lambda \eta \dot{\zeta})$ to write about Paul to King Agrippa. This concept of needing an examination in order to determine the certain truth is a similar idea to what we find in Luke's prologue. Luke conducted careful investigations ( $\operatorname{Lk} 1: 3$ ) in order to produce a document that would verify the events and teachings of Jesus with certainty (Lk 1:4). What Theophilus has to gain by a reading of the narrative is a secure validation of the message about which he had previously received partial information.

\section{The importance of word order}

An examination of word order further displays Luke's intention to deliver the facts about Jesus to Theophilus in an accurate manner. A.T. Robertson (1934:417) notes that the propensity of the Greek language to enjoy a 'freedom [...] from artificial rules' is seen especially in matters related to word order. A word may be removed from its expected position and placed in an unusual one - typically, either in the beginning or ending of a sentence - for the purpose of emphasis (Robertson ibid; Porter 1999:296; Dover 2010:32). There are two conspicuous instances of unexpected word order in the prologue.

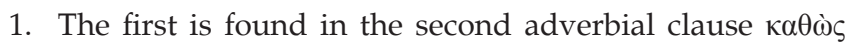

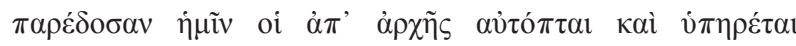

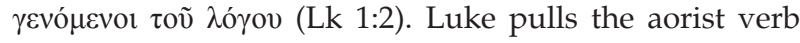
$\pi \alpha \rho \varepsilon \varepsilon \delta$ co $\alpha v$ out of the usual word order and places it in

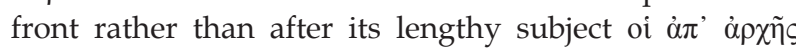

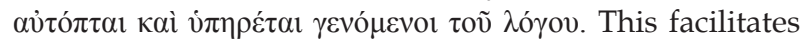
the placement of $\pi \alpha \rho \varepsilon \delta \delta \sigma \alpha \nu$ immediately after $\kappa \alpha \theta \omega \varsigma$. Thus, Luke highlights both the deliberate handing down of the accounts and the unchanged nature of those accounts. Events were narrated just as handed down (Alexander 1993:118-119; Bock 1994:57-59; Green 1997:40). Theophilus may be assured of the reliability of Luke's sources - the entrusted accounts.

2. The second major instance of unexpected word order is found in the final adverbial clause iv $v \alpha \dot{\varepsilon} \pi \nu v \tilde{\omega} \varsigma \pi \varepsilon p i$

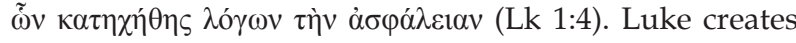

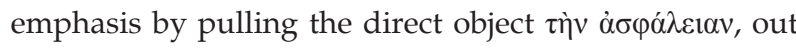
of the expected order (which would be after the verb $\dot{\varepsilon} \pi \imath v(\tilde{\omega} \varsigma)$ and transplanting it to the end of the sentence. The driving force behind all of Luke's research and writing is that Theophilus would know the secure truth.

A second matter pertinent to word order is a Greek manner to create a unified concept. In such a construction, an author introduces a unified concept by separating the article and the noun it modifies. The contents in-between the article and noun may be central to the unified concept (Robertson 1934:418). Two of these unified concepts appear in the prologue. The first appears in the first adverbial clause $\pi \varepsilon \rho i$

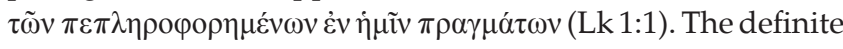
article $\tau \tilde{\omega} v$ is separated from $\pi \rho \alpha \gamma \mu \alpha \dot{\tau} \omega v$, the noun it modifies and thereby bringing focus onto the central portion of the unified concept: $\pi \varepsilon \pi \lambda \eta \rho о \varphi о \rho \eta \mu \varepsilon ́ v \omega v \dot{\varepsilon} v \dot{\eta} \mu \mathrm{i} v$. Luke emphasises the fact that the events actually happened in two ways: through word order and also by using a perfect participle ( $\pi \varepsilon \pi \lambda \eta \rho о \varphi о \rho \eta \mu \varepsilon ́ v \omega v)$. Loveday Alexander (1993:113) also notes the high style of this clause, with its alliteration and 'sandwiching of noun and article'. The second unified concept appears in the second adverbial clause, oi $\alpha \dot{\alpha}$ ' $\dot{\alpha} \rho \chi \tilde{\eta} \varsigma$

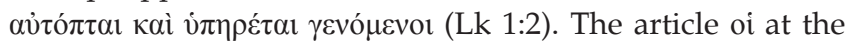
beginning of the clause modifies the substantive participle $\gamma \varepsilon v o$ ofvor which is placed at the end of the clause $\dot{\alpha} \pi$,

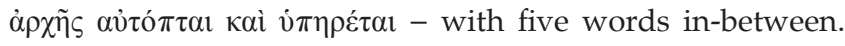
Alliteration may again be noted. Luke's stylistic emphasis underlines the importance and nature of the eyewitnesses. What Theophilus is about to read is true - in contrast to the mythological fabrications of the Greco-Roman religions in the world around him.

Thus, Luke uses style and grammar to intensify his statement regarding the credibility of his sources. Credibility and 
reliability are key foundations for Luke-Acts. These emphases bring Luke's purpose into sharp focus: to give solid evidence, so that Theophilus may be fully assured of the truth.

\section{The necessity of accuracy in historical writing}

Luke's concern for accuracy in his writing, as carefully presented in the prologue of his gospel, is in keeping with standards for best practices amongst other historians of the Hellenistic period. The historian Polybius (1889) (2nd century BC) criticised a certain Timaeus for inventing speeches rather than recording the actual words:

The special province of history is, first, to ascertain what the actual words used were; and secondly, to learn why it was that a particular policy or argument failed or succeeded [...] The historian therefore who omits the words actually used, as well as all statements of the determining circumstances, and gives us instead conjectures and mere fancy compositions, destroys the special use of history. In this respect Timaeus is an eminent offender, for we all know that his books are full of such writing. (Hist. 12.25)

Continuing his negative evaluation of the writing of Timaeus, Polybius (1889) asserts the necessity of carefully researching a topic through personal investigation:

Study of documents involves no danger or fatigue, if one only takes care to lodge in a city rich in such records, or to have a library in one's neighbourhood. You may then investigate any question while reclining on your couch, and compare the mistakes of former historians without any fatigue to yourself. But personal investigation demands great exertion and expense; though it is exceedingly advantageous, and in fact is the very corner-stone of history. (Hist. 12.27)

It seems that Luke builds his work on the foundations of personal investigation, according to Polybius' advice, employing the exertion and expense that would have been associated with such research.

Lucian (2nd century AD) also stressed accuracy in historical writing and the importance of eyewitness investigation. In his work, How to write history, Lucian (1959) describes the careful historian:

As to the facts themselves, he should not assemble them at random, but only after much laborious and painstaking investigation. He should for preference be an eyewitness, but, if not, listen to those who tell the more impartial story. (VI. 47)

In Luke's case, he used his own eyewitness account for portions of Acts (the 'we passages'; Schnabel 2012:39-40) and sought other eyewitness reports for events where he himself was not present.

\section{Luke's accuracy summarised}

If 'Luke, the beloved physician' of Colossians 4:14 is the same Luke as the author of Luke-Acts, ${ }^{4}$ we may surmise that the author was accustomed to giving rigorous attention to detail. The abilities required of a physician - careful observation 4.For discussion of Luke as a physician, see recent scholarship by Craig Keener (2012:410-420) and Eckhard Schnabel (2012:25). and examination skills - might have transferred to Luke's approach to research methodology. For a doctor, even a single error in examination or treatment may yield disastrous results. It seems that Luke researched the contents of his gospel with the same meticulous care required of a medical practitioner. Luke's research took him right back to the source of the narrative accounts. Luke consulted eyewitness sources before compiling his narrative (Lk 1:2-3) in keeping with good practices for ancient historians. ${ }^{5}$ Luke took pains with his research so that he might narrate the events and teachings associated with Jesus' life with accuracy. Theophilus had a need for a full and accurate account of Jesus and the events surrounding the spread of Christianity throughout the Roman Empire.

\section{Conclusion}

This article has provided some key information regarding the possible identity of Theophilus as reader of the LukeActs narrative. Theophilus was, likely a person of social and government rank, and a Gentile with a background in Roman and Greek culture. The generous inclusion of Old Testament texts suggests that Theophilus would have also had a background with the Jewish culture. Theophilus had already received some instruction about Jesus, likely of an introductory nature, at some point. This shows that he had an interest in Christianity, but needed more teaching and factual verification. Theophilus may be assured that faith in Jesus rests on verified historical facts, unlike the mythology surrounding Greco-Roman religions. Because of this verification, Theophilus may have full confidence in the truth of the message and proclaim it with boldness in accordance with Acts 1:8. If a Roman official, Theophilus would have had a wide sphere of influence upon people from all walks of life. He also would have had a unique opportunity to explain the message of Jesus to others in like positions. From this, it would seem that Luke had high hopes for his audience of one.

\section{Acknowledgements Competing interests}

The authors declare that they have no financial or personal relationship(s) that may have inappropriately influenced them in writing this article.

\section{Authors' contributions}

J.M.C. (North-West University) conducted the research under the supervision of A.B.S. (North-West University) and F.P.V. (North-West University).

\section{References}

Alexander, L., 1993, The preface to Luke's gospel, Cambridge University Press, Cambridge. http://dx.doi.org/10.1017/СBO9780511554827

Barclay, J., 2007, Against Apion: Translation and commentary, Brill, Leiden.

Bauer, W., 2000, A Greek-English lexicon of the New Testament and other early Christian literature, 3rd edn., University of Chicago Press, Chicago. (BibleWorks version 9, computer software).

5.See also Moles (2011), who argues for Luke's historiography as superior to that of classical historians. 
Bauman, M. \& Klauber, M., 1995, Historians of the Christian tradition, Broadman \& Holman, Nashville.

Blomberg, C., 2006, From Pentecost to Patmos: An introduction to Acts through Revelation, Broadman \& Holman, Nashville.

Bock, D., 1994, Luke, Baker, Grand Rapids.

Bock, D., 2007, Acts, Baker, Grand Rapids.

Bovon, F., 2006, Luke the theologian, 2nd edn., Baylor, Waco.

Bruce, F.F., 1976, 'Is the Paul of Acts the real Paul?', Bulletin of the John Rylands University Library of Manchester 58(2), 282-305.

Bruce, F.F., 1990, The Acts of the Apostles: Greek text with introduction and commentary, 3rd edn., Eerdmans, Grand Rapids.

Cadbury, H., 1922, 'Commentary on the Preface of Luke', in F. Jackson \& K. Lake (eds.), The beginnings of Christianity Part 1: The Acts of the Apostles, pp. 489-510, Macmillan, London.

Conzelmann, H., 1987, Acts of the Apostles, Fortress Press, Philadelphia.

DeSilva, D., 2000, Honor, patronage, kinship \& purity: Unlocking New Testament culture, InterVarsity, Downers Grove.

Dibelius, M., 1956, Studies in the Acts of the Apostles, transl. M. Ling, SCM, London.

Dover, K., 2010, Greek word order, Cambridge University Press, New York.

Eusebius, 2007, The church history, transl. P. Maier, Kregel, Grand Rapids.

Friberg, T., Friberg, B. \& Miller, N., 2000, Analytical lexicon to the Greek New Testament Baker, Grand Rapids. (BibleWorks version 9, computer software).

Garland, D., 2011, Luke, Zondervan, Grand Rapids.

Garrison, R., 2004, The significance of Theophilus as Luke's reader, Edwin Mellen Press, Lewiston.

Gempf, C., 1993, 'Public speaking and published accounts', in B. Winter \& D. Clarke (eds.), The book of Acts in its first century setting, pp. 259-303, Eerdmans, Grand Rapids.

Green, J., 1997, The gospel of Luke, Eerdmans, Grand Rapids.

Haenchen, E., 1971, The Acts of the Apostles: A Commentary, Westminster Press, Philadelphia.

Hemer, C., 1977, 'Luke the historian', Bulletin of the John Rylands University Library of Manchester 60(1), 28-51.

Hemer, C., 1989a, 'Speeches of Acts II', Tyndale Bulletin 40(2), 239-259.

Hemer, C., 1989b, The book of Acts in the setting of hellenistic history, Mohr Siebeck, Tübingen.

Hengel, M., 2012, 'The Lukan prologue and its eyewitnesses: The apostles, Peter and the women', transl. N. Moore, in M. Bird \& J. Maston (eds.), Earliest church history, pp. 533-587, Mohr Siebeck, Tübingen.

Holmes, M. (ed.), 1989, The apostolic fathers, 2nd edn., transl. J. Lightfoot \& J. R. Harmer, Baker, Grand Rapids.

Jefford, C., 2012, Reading the apostolic fathers, Baker, Grand Rapids.
Johnson, L., 1991, Luke, Liturgical Press, Collegeville.

Josephus, 1926, Works, transl. H. Thackeray \& R. Marcus, Harvard University Press, Cambridge.

Josephus, 1978, The works of Josephus, transl. W. Whiston, Hendrickson Publishers, Peabody.

Keener, C., 2012, Acts: An exegetical commentary. Introduction and 1:1-2:46, Baker, Grand Rapids.

Larkin, W., 1995, Acts, InterVarsity, Downers Grove.

Liddell, H. \& Scott, R., 1996, A Greek-English lexicon, 9th edn., Clarendon, Oxford.

Louw, J. \& Nida, E., 1989, Greek-English lexicon of the New Testament based on semantic domains, 2nd edn., United Bible Societies, New York. (BibleWorks version 9 , computer software)

Lucian, 1959, Lucian, transl. K. Kilburn, Harvard University Press, Cambridge.

Marshall, I.H., 1980, Acts, Eerdmans, Grand Rapids.

Marshall, I.H., 1988, Luke: Historian \& theologian, InterVarsity, Downers Grove.

Mason, S., 2001, Life of Josephus: Translation and commentary, Brill, Leiden.

Moles, J., 2011, 'Luke's preface: The Greek decree, classical historiography and Christian redefinitions', New Testament Studies 57(4), 461-482. http://dx.doi. org/10.1017/S0028688511000154

Moulton, J. \& Milligan, G., 1930, Vocabulary of the Greek Testament, Hodder and Stoughton, London. (BibleWorks version 9, computer software).

Peterson, D., 2009, The Acts of the Apostles, Eerdmans, Grand Rapids.

Polhill, J., 1992, Acts, Broadman Press, Nashville.

Polybius, 1889, 'Histories', in Perseus, transl. E. Shuckburgh, Macmillan, New York, viewed 12 November 2013, from http://www. perseus.tufts.edu/hopper/text?doc $=P \mid b .+12.25 \&$ fromdoc $=$ Perseus\%3Atext\%3A1999.01.0233

Porter, S., 1999, Idioms of the Greek New Testament, Sheffield Academic Press, London.

Robertson, A.T., 1934, A grammar of the Greek New Testament in the light of historical research, Broadman Press, Nashville.

Rosner, B., 1998, 'The progress of the word', in D. Peterson \& I.H. Marshall (eds.), Witness to the gospel: The theology of Acts, pp. 215-234, Eerdmans, Grand Rapids.

Schnabel, E., 2012, Exegetical commentary on the New Testament, Zondervan, Grand Rapids.

Stein, R., 1992, Luke, Broadman Press, Nashville.

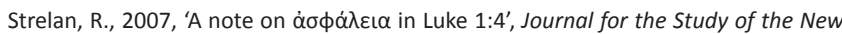
Testament 30(2) 163-171. http://dx.doi.org/10.1177/0142064X07084774

Thayer, J., 1997, Greek-English lexicon of the New Testament: Abridged and revised Thayer lexicon, Online Bible Foundation, Ontario. (BibleWorks version 9, computer software).

Thompson, M., 2011 'Paul in the book of Acts: Differences and distance', Expository Times 122(9), 425-436. http://dx.doi.org/10.1177/0014524611401528

Wallace, D., 2000, The basics of New Testament syntax, Zondervan, Grand Rapids. 